\title{
Well-being and conservation: diversity and change in visions of a good life among the Maasai of northern Tanzania
}

\author{
Emily Woodhouse ${ }^{1}$ and $\underline{J}_{\text {. Terrence McCabe }}{ }^{2,3}$
}

\begin{abstract}
The Simanjiro plains, east of Tarangire National Park in Northern Tanzania are a key dispersal area for wildlife, and are of vital importance to Maasai pastoral livelihoods, which are rapidly diversifying. Diversification is coupled with fragmentation of the rangelands as agriculture expands and multiple actors compete for land. These changes reflect transformations occurring across pastoral rangelands, and pose the broader challenge of reconciling conservation and development objectives. We propose that qualitative research using a three-dimensional human well-being framework, encompassing material, relational, and subjective aspects, can inform locally legitimate and socially just conservation. Through semistructured group interviews across four villages, we explore well-being conceptions of Maasai men and women in Simanjiro. In particular we focus on the value of understanding social complexity for conservation research in the form of (i) the heterogeneity of conceptions of well-being across gender, age groups, and villages; (ii) temporal dynamics in notions and experiences. Material assets, namely land (for grazing and agriculture) and livestock are important to people but are intertwined with other aspects of well-being. Subjective well-being is centered on concerns about future security, especially with regards to land. Autonomy and social unity (relational dimension) are key priorities. We reflect on the implications for conservation at the study site, and more broadly on how well-being can better be incorporated into policy and practice that takes social justice seriously. The diversity we find in well-being priorities and experiences shows the importance of taking a disaggregated approach that conceptualizes benefits and burdens across a range of locally important well-being components ensuring the priorities of the most marginalized groups are represented.
\end{abstract}

Key Words: equity; gender; justice; pastoralism; rural livelihoods; social-ecological systems; tenure security

\section{INTRODUCTION}

Much of the literature on pastoral peoples around the world published over the last 20 years has concerned the diversification of pastoral livelihoods and the fragmentation of the rangelands on which livestock depend. This is especially true for East Africa where droughts and disease have reduced livestock numbers in some areas forcing poorer people to both adopt cultivation and to migrate to urban areas in search of employment (Homewood et al. 2009, McCabe et al. 2014). At the same time more wealthy people have adopted cultivation to preserve the livestock that they have and because "modern" Tanzanians grow maize and beans for home consumption and trade (McCabe et al. 2010). Others may use diversification as a risk management strategy in the face of unpredictable ecological and economic changes (Little et al. 2001). Coupled with the diversification of pastoral livelihoods has been the fragmentation of rangelands that restricts the mobility of pastoralists and therefore their ability to access resources in dynamic systems (Galvin 2009). In Kenya, fragmentation has been driven by the implementation of group ranches and their subsequent breakup with individual households receiving title deeds (BurnSilver 2007). In Tanzania, the establishment of village boundaries has imposed some restrictions on the movement of livestock, and the allocation of individual land holdings has fragmented the rangelands within village boundaries. As the human population increases, villages divide further constraining the mobility of livestock and increasing pressure on local resources. The establishment of National Parks and other protected areas has restricted access to important resources for pastoral peoples. For northern Tanzania, the creation of the Serengeti, Manyara, and Tarangire National Parks and the Ngorongoro Conservation Area, have had major impacts on how Maasai pastoralists use the land, and manage natural resources (McCabe 2002, Igoe 2010, Goldman 2011, Gardner 2016). In addition, private concessions, based on wildlife conservation and large commercial farms have constrained mobility options that have been critically important in times of drought.

This complex and dynamic set of interactions involving policy decisions at multiple scales, household livelihood decisions, increasing human populations, and mounting evidence of climate change impacts pose significant challenges to the Maasai pastoralists and agro-pastoralists living in northern Tanzania. They also pose the question of how to reconcile the goals of conservation - to protect wildlife and prevent the rangelands from further fragmentation-with protecting the rights and meeting the needs of local communities. Over the last two decades, several major initiatives have promoted expanding the way in which development policy measures societal development away from economic production toward people's well-being (Stiglitz et al. 2009, OECD 2017). This acknowledges that a narrow incomefocused framing of poverty is insufficient to deal with global problems such as environmental change (McGregor and Sumner 2010). Likewise, conservation policy and that of many organizations has moved beyond the standard livelihoods and income-based approach to dealing with the social costs of conservation and instead emphasizes human rights, equity, and well-being (Springer and Campese 2011, Schreckenberg et al. 2016). There are both instrumental and ethical reasons for this shift. There is evidence that attention to social justice can improve local legitimacy and the effectiveness of conservation interventions (Martin et al. 2014, Cetas and Yasué 2016), but research also suggests that conservation interventions that focus

${ }^{1}$ University College London, Department of Anthropology, ${ }^{2}$ University of Colorado Boulder, Department of Anthropology, ${ }^{3}$ University of Colorado Boulder, Institute of Behavioral Science 
on enforcement can meet ecological goals despite negative social costs (Brockington 2004). The moral basis for advancing equity and human well-being is clearer, and aligns with international policy such as the commitment of the UN sustainable development goals (SDGs) to address "poverty in all its forms" and promote equity. However, strategies for creating positive synergies between social and ecological goals remain challenging. In Northern Tanzania, despite the rhetoric of community-based conservation, local knowledge and needs are often sidelined (Goldman 2003, Bluwstein et al. 2016).

We propose that qualitative research processes that enable understandings about local conceptions of well-being can provide insights into livelihood decisions and suggest routes toward more locally legitimate and socially just management strategies. There is an increasing convergence on the concept of well-being as representing a positive physical, social, and mental state (Stiglitz et al. 2009), encompassing material, relational, and cognitive elements. The notion of well-being moves development thinking away from financial indicators to a more multidimensional idea of success accounting for the aspects of people's lives that they value. It highlights the complexity of people's lives, incentives, and aspirations, which are both shaped by and shape their natural environment. Although conservation research is starting to employ a multidimensional well-being approach to understanding impacts, it does not often tackle aspects of social complexity. Structural differences across different groups, e.g., age, gender, wealth, can affect well-being aspirations and achievement (McGregor et al. 2008, Daw et al. 2011, Dawson and Martin 2015). Social meanings, constructed through relationships in particular cultural contexts, shape ideas of a good life and experiences of well-being (Mathews and Izquierdo 2009, Coulthard et al. 2011). In the context of dynamic social-ecological systems, well-being ideas and outcomes are also not static but constantly shifting (McGregor 2007). We use a qualitative and historically and culturally situated approach to understand conceptions of well-being in the Simanjiro Plains of Northern Tanzania, identifying variations across men and women, different age-groups, and between villages at different distances from Tarangire National Park. We ask what the implications are for reconciling the conservation and development challenges, and more broadly, what our results suggest for integrating human wellbeing into conservation policy and practice that attends to justice.

\section{A three-dimensional human well-being framework}

The well-being approach used in this study is based on the threedimensional framework developed by the Wellbeing in Developing Countries (WeD) research group. Well-being is defined as a state of being with others, which arises where human needs are met, where one can act meaningfully to pursue one's goals and where one can enjoy a satisfactory quality of life (McGregor 2007). It is conceptualized in three interacting dimensions: (i) the objective material circumstances of a person; (ii) subjective evaluation of one's own life, and the meanings and values ascribed to the processes one engages in and the outcomes of those processes; (iii) a relational component focusing on how people engage with others to meet their needs and achieve goals (McGregor and Sumner 2010). This last dimension acknowledges that individual well-being is pursued in relation to other people, that social connectedness is a human need, and that definitions of a good life are socially constructed (Deneulin and McGregor
2010). The framework does not define what constitutes well-being in any particular context, but provides structure for investigating local conceptions and experiences.

The framework draws upon the capabilities approach developed by Amartya Sen and Martha Nussbaum, which suggests that human well-being lies not only in what people have or in the fulfilment of desires, but in what people can do and be. Development is envisioned a having the freedom or capability to live the life that you have reason to value, with different people valuing different things. The approach accepts that people will achieve different outcomes even with similar commodities because of having varying freedoms and subjective preferences (Sen 1985, Nussbaum 2011). Focusing only on subjective wellbeing experiences, as in some approaches, may fail to recognize material impoverishment, by not accounting for adaptation to harsh conditions.

\section{METHODS}

\section{Study site}

Research took place in four villages within Simanjiro District in northern Tanzania: Loiborsoit, Emboreet, Sukuro, and Terrat. Simanjiro District is located within the Tarangire-Manyara region of Tanzania, considered to be one of the most biodiverse grassland ecosystems on the planet (Olson and Dinerstein 1998). Lying east of Tarangire National Park (TNP), the Simanjiro Plains are fertile grasslands that provide critical grazing and calving areas for wildebeest and zebra during the wet season (Gereta et al. 2004). Rainfall in Simanjiro averages between 575 to $650 \mathrm{~mm}$ per year, and is highly variable both temporally and spatially with drought being a common climatic feature (Prins and Loth 1988). The Simanjiro plains have often been areas where people and livestock have dispersed from, as well as a refuge area for people and livestock suffering from drought in other areas, as occurred in the 2008/2009 drought. The communities of Simanjiro are predominantly Kisongo Maasai people, as well as small numbers from a variety of other ethnic groups (Ndagala 1992).

Maasai have traditionally coped with variability in resource availability through daily and seasonal mobility within and across territorial sections (olosho), facilitated by social institutions that allow access to natural resources to outsiders in times of stress (Homewood 2008). Maasai society is structured around two major social institutions: the age-set system and the clans. Each man after circumcision is incorporated into an age-set in which he passes with his cohort through stages associated with certain responsibilities: warrior, junior elder, senior elder, and retired elder (Spencer 1993). Senior elders hold significant authority over decisions regarding resource use, livestock, and land among other issues. Maasai also hold membership of patrilineal clans that traditionally structure the management of water resources and mutual aid during times of stress.

More than a decade after the independence of Tanzania in 1961, the government imposed the socialist policy of "villagisation" (called Operation Imparnati in Maasailand) that required people to settle in permanent villages with designated areas for settlements, cultivation, and livestock keeping. Although this policy never really took hold in Maasailand, it was the basis for the formation of villages (Ndagala 1982, O’Malley 2000). Natural 
Fig. 1. Map of study villages in northern Tanzania.

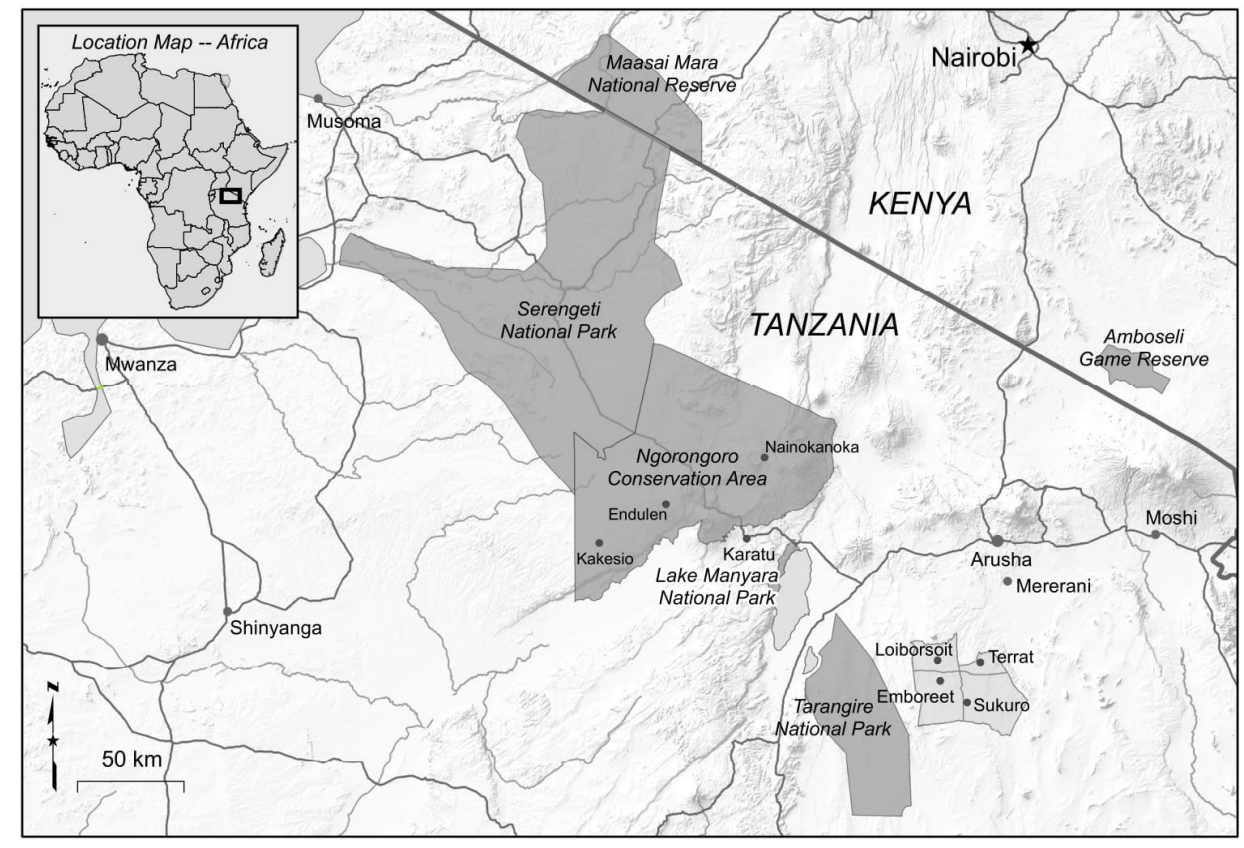

resources and mobility are now managed by a combination of traditional pastoral institutions and village by-laws, although where villages are within wildlife management areas (WMAs) ${ }^{[1]}$ the central government plays a significant role (Wright 2017). Most Maasai homesteads are now semipermanent, but livestock continue to be mobile within village lands and across village boundaries in times of stress. The household unit (olmarei), which is often polygamous and includes a man, wives, children, and other dependents, is responsible for management of livestock and cultivation, with more than one household often sharing a homestead enclosure (engang).

Through a range of processes including colonial policies, international development programs, large-scale agriculture, immigration, and conservation areas, Maasai are faced with increasing pressures on their land (Igoe and Brockington 1999, Fratkin 2001, Igoe and Croucher 2007). The fact that human populations have grown and livestock populations remain stable has added pressure to pastoralist livelihoods (McCabe 2003). In response, Maasai have diversified their livelihoods into agriculture (Homewood et al. 2009, McCabe et al. 2010) and wage labor including migration to urban areas and to the Tanzanite gem mines (Smith 2012, McCabe et al. 2014). Women's labor that traditionally centers on milking livestock, taking care of small livestock, and household tasks has diversified to include income generating activities including petty trading at local markets, and involvement in agriculture (Homewood et al. 2009, Smith 2014). The expansion of cultivation has been a particular concern for conservationists because the Simanjiro plains are the wet season dispersal area for many of the animals living in Tarangire National Park. For both wildebeest and zebra, the plains are a critical calving area and cutting off access to them could seriously impact conservation efforts both within and outside of the Park (Msoffe et al. 2011). It is clear that wildlife numbers have been in decline and land fragmentation and conversion to cultivation are likely significant contributing factors (Mtui et al. 2017).

Tarangire National Park was created in 1970 and this created hardships for the Maasai living in our study area. Access to the Tarangire River and the Silalo Swamp were no longer possible, and it has been argued that the pasture and water resources within what is now the park were extremely important, especially as a drought reserve, to Maasai households living in Simanjiro (Igoe and Brockington 1999, Sachedina 2008). However, it has also been argued that the grazing and water in what is now the park were primarily used for small stock and only occasionally used by cattle (Miller et al. 2014). Nevertheless, Tarangire National Park continues to impact people in Simanjiro in various ways, exposing them to the risk of crop damage by migrating wildlife (Baird et al. 2009), but has also increased development activities and improved infrastructure (Baird 2014). Despite efforts to establish conservation areas on the Simanjiro plains, most recently a WMA, these have been strongly resisted by the villages in our study (Benjaminsen et al. 2013). One exception has been the establishment of the Simanjiro Conservation Easement in which NGOs and tourism companies have contributed approximately US\$4500 per year to each village participating in the easement in exchange for not establishing settlements or cultivation on the designated land (Nelson et al. 2010). The easement was first established in the village of Terrat in 2006 but since then the village of Sukuro has also joined (Fig. 1). There are a number of tourist camps and hunting blocks within the village boundaries of our four study villages and these have generated some revenue for local people. However, elite capture has to a large extent prevented most local people from benefiting from this source of income (Sachedina 2008). 
Table 1. Study village characteristics.

\begin{tabular}{|c|c|c|c|c|c|}
\hline Village & $\begin{array}{l}\text { Distance from park } \\
\text { to center }(\mathrm{km})^{\dagger}\end{array}$ & $\begin{array}{c}\text { TLUs }^{\star} / \text { household }^{2014^{\S}}\end{array}$ & $\begin{array}{c}\text { Hectares } \\
\text { allocated to } \\
\text { household } \\
2014^{\S}\end{array}$ & $\begin{array}{l}\text { Hectares cultivated/ } \\
\text { household } 2014^{\S}\end{array}$ & Relevant interventions and information \\
\hline Emboreet & 15 (adjacent) & $\begin{array}{c}27.5(\text { mean }) \\
21.0(\text { median })\end{array}$ & $\begin{array}{l}20.2 \\
20.2\end{array}$ & $\begin{array}{c}3 \\
2.8\end{array}$ & $\begin{array}{l}\text { First village to establish cultivation through leasing } \\
\text { land to WaArusha agriculturalists. } \\
\text { Game Controlled Area extends across village land. }\end{array}$ \\
\hline Loiborsoit & 25 (adjacent) & $\begin{array}{l}58.8 \\
32.8\end{array}$ & $\begin{array}{c}12 \\
8\end{array}$ & $\begin{array}{l}4.8 \\
3.2\end{array}$ & $\begin{array}{l}\text { Highest levels of development interventions and } \\
\text { external engagement. } \\
\text { High levels of land leasing for agriculture. } \\
\text { Recently lost dry season grazing land to a private } \\
\text { conservancy. } \\
\text { Set aside tracts of land for communal grazing. }\end{array}$ \\
\hline Sukuro & 40 (not adjacent) & $\begin{array}{c}115.8 \\
58.7\end{array}$ & $\begin{array}{c}11.5 \\
12\end{array}$ & $\begin{array}{l}3.3 \\
3.2\end{array}$ & $\begin{array}{l}\text { Conservation easement (established 2009) } \\
\text { Set aside grazing land for future allocation to } \\
\text { individuals. }\end{array}$ \\
\hline Terrat & 45 (not adjacent) & $\begin{array}{l}47.8 \\
34.3\end{array}$ & $\begin{array}{c}10.9 \\
6.5\end{array}$ & $\begin{array}{l}3.4 \\
3.2\end{array}$ & $\begin{array}{l}\text { Conservation easement (established 2006) } \\
\text { Olmoti ranch development project established } \\
2009 \text { (caused dispute with Sukuro village). }\end{array}$ \\
\hline
\end{tabular}

${ }^{\dagger}$ Estimate taken from Baird et al. 2009.

Tropical Livestock Units: standardized measure of livestock holdings accounting for differences across species.

${ }^{\S}$ Unpublished data supplied by J. Terrence McCabe and Paul W. Leslie.

'Game Controlled Areas are designated areas for controlled hunting. Other human activities (grazing and agriculture) are permitted but can conflict with hunting areas.

The Village Land Act of 1999 established the village administration authority to manage village land and resources, including the allocation of individual plots to village members that continues today. Although no title deeds have been issued, individual allocations of between 4 to 20 ha are common. Although individuals are not allowed to sell these allocations, it is not uncommon to see large plots of land "leased" to outside interests for commercial agriculture. The regional government declared a moratorium on new farms on the plains in 2006, fuelling fears among local people that they would lose land (Davis 2011). Alongside processes of land allocation, village administrations have developed land use plans often supported by NGOs, to specify areas for cultivation, herding, and sometimes conservation.

Other important changes that have influenced the lives and wellbeing in our study villages are the spread of cell phones and the introduction of small motorcycles. These have vastly improved communication and access to markets and health centers.

\section{Data collection methods}

We carried out the study in four villages lying in the Simanjiro District (Figure 1). Two are adjacent to the park border and two are near but not adjacent; villages have different levels of wealth, project interventions, land use policies, and land cover and histories (Table 1). Each village has plains used by wildlife migrating from Tarangire National Park. These villages have been the focus of long-term research by McCabe and colleagues over the last 12 years (Baird et al. 2009, Leslie and McCabe 2013, McCabe et al. 2014), and were chosen because of their location in the key dispersal area for wildlife, and the fact that they are undergoing rapid changes via conservation, development, and wider socioeconomic shifts likely to affect well-being.
The research is primarily based upon 26 semistructured group interviews carried out across the four villages of Emboreet, Loborsoit, Sukuro, and Terrat between January and August 2014. Men's and women's groups were conducted separately; a total of 76 men and 72 women were interviewed in 14 and 12 interviews, respectively. Interviews were carried out with the assistance of local Maasai field assistants fluent in Maa (the Maasai language), Swahili, and English. McCabe and two male field assistants carried out the interviews with men; and Woodhouse and a female assistant conducted those with women. Participants were not randomly selected because of logistical difficulties of bringing together a diverse group from different households in a sparsely populated landscape, and instead local knowledge and contacts allowed us to prearrange interviews. We sought to include a range of age-sets, and households from different subvillages and representing different wealth statuses. Age-sets included in the men's interviews were the following: Esuri (estimated age based on circumcision at age 15: 59-78 years old); Makaa (48-60 years); Landes (37-50 years); and Korianga (21-35 years). Young men of the most recent Nyangulo age-set (15-20 years) were generally not present; this age-set had only recently opened at the time of research. Different generations of women were also included within each group interview. Female key informants described age groups that are commonly used among Maasai, and women self-categorized in the interviews. The age groups included were the following: Endoyie (unmarried girl); Siangiki (approx. 20-32 years, a few children); Endasati (approx. 33-49 years; maybe a grandmother); Koko (beyond reproductive years) ${ }^{[2]}$.

A qualitative approach enabled flexibility in the research process with data being collected iteratively allowing themes that emerged to be explored further in subsequent interviews. It also allowed people to express nuance in their own language on their ideas of well-being, highlighting processes and relationships between 
different aspects (Woodhouse et al. 2015). Group interviews have the advantage of drawing out both points of debate and commonalities, and have been employed successfully in this cultural context (e.g., Miller et al. 2014, Baird and Gray 2014). Discussions with two key informants (men from Simanjiro who McCabe has known for several years) helped us to translate the concept of well-being and introduce the research in an understandable way in Maa. Well-being was described as having a "good life" (engishui sidai) that was moderated during the introduction to "normal life" (engishui e kawaida) because initial interviews became too focused on aspirations. We asked the following key questions regarding individual well-being, with probing for detail on themes that emerged, and encouragement of discussion and answers from all participants:

1. What is important (for you to have and do) in this community to feel that you have a good life?

2. Why is this important? (What does it provide or promote?)

3. How has this aspect of your life changed in the last 10 years (marked by the eunoto ceremony of 2005 when the Korianga age-set were promoted to senior warriorhood)?

4. Why has it changed?

5. Are the changes the same for everyone here? In this village?

6. What threatens this aspect of your life in the future?

We also carried out one key informant interview in each village (with men who hold and have held leadership positions in the village) on village histories, conservation and development interventions, and institutions. In addition, the analysis draws upon ethnographic fieldwork and participant observation over the last 12 years in the study villages by McCabe.

Data analysis of transcripts and notes from the interviews was guided by the three dimensions of well-being but was inductive in that the specific components of well-being and the reasons given for their importance (as shown in Table 2), relationships, and processes emerged from the data through coding carried out by Woodhouse. We tested emerging ideas iteratively through the analysis, inspecting for recurring instances and differences to ensure comprehensive treatment of the data set (Silverman 2006). We chose not to do a formal ranking exercise as in other studies of well-being (Abunge et al. 2013, Buzinde et al. 2014) and instead focused on interrelationships, and inspected for patterns of emphasis and occurrence of different themes across different villages, age groups, and between men and women.

\section{RESULTS}

\section{Components of well-being for men}

Men discussed a variety of elements to having a good life during interviews. There were consistent patterns in what was focused upon with priorities for younger men (Korianga age-set) differing from the older men (see Table 2). Livestock (primarily cows, but also goats and sheep) was consistently the first priority given in interviews by all generations.

For all Maasai, livestock is important. If you have no livestock, no children, or no land, you have nothing. (Landis, senior elder, Terrat village)
Livestock are central to livelihoods but also cultural identity, status, and dignity.

\section{[If you didn't have livestock] other people would consider you Dorobo ${ }^{[3]}$, and ask what kind of Maasai is that? Your role in the village would change and no one would listen to you about livestock issues. (Korianga, junior elder, Sukuro village)}

The number of livestock required varied according to respondents within groups and tended to be higher in Terrat. On probing, what was deemed important was that the herd would enable you to do what you wished. The capabilities livestock provided differs between age groups. The older men focused on providing enough milk for the family, and being able to sell livestock for money, food, and clothing. Korianga emphasized, in addition, the ability to send children to school, to cultivate crops, and to build a house. It was primarily men in the Korianga age-set that mentioned a strategy of keeping fewer livestock but investing in higher quality breeds of greater value and resiliency to drought.

Other material assets such as a modern concrete block house rather than a traditional one ${ }^{[4]}$ and a means of transport were important for Korianga men. Men across age groups recognized the increasing importance of being closer to services such as health clinics, water sources, access to veterinary drugs, and material goods, as well as markets for selling and buying livestock. Although livestock remain mobile, because of increasing populations and environmental change, a more sedentary life centered on villages and subvillages is increasingly desirable and necessary.

Traditionally in Maasai society, a big family with many children is needed for labor and is an important indicator of wealth, and this idea remained strong among many older men, but generated some debate. The process of having children is a means of reproducing the social structure and hierarchy: "you can't be an elder if you don't have children." Wives were only mentioned in relation to having children. Although some older men in Simanjiro have as many as 10 wives, younger men (Landis and Korianga age-sets) told how it is now considered normal to have two wives, each expected to have four to five children.

Things have changed. If you have lots of children, you
need resources. Before, people needed man power. You
just needed simple knowledge, where to move to for
grazing ... but now we need more than that. (Korianga,
junior elder, Sukuro village)

The topic of land and its centrality to life focused discussions around the value of herding versus agriculture for livelihoods and broader well-being. Linked to this was the relative value of communal land used for grazing and private plots primarily for growing crops (maize and beans). Men across all the age-sets recognized the importance of owning a piece of land, signifying the shift away from a nomadic lifestyle. This land is needed for a permanent house, agriculture, and a reserve for calves and sick animals (olekeri). For men, agriculture enables the possibility of increased food for the family rather than being reliant on trade, and provides a sense of security during years when there is drought or disease resulting in livestock losses. Crucially, it secures land in the face of increasing threats from a growing population and land-grabbing: 
Table 2. Summary of aspects of well-being disaggregated by age-group and gender. Blank cells indicate no differences to general description.

\begin{tabular}{|c|c|c|c|c|}
\hline \multirow{2}{*}{$\begin{array}{l}\text { Dimension } \\
\text { Component of well- } \\
\text { being }\end{array}$} & \multirow[b]{2}{*}{ Reasons provided } & \multicolumn{3}{|c|}{ Variations across different groups } \\
\hline & & Younger men (Korianga) & Older men & Women \\
\hline \multicolumn{5}{|l|}{ Material } \\
\hline Livestock & $\begin{array}{l}\text { Wealth; security; enabling choice } \\
\text { and freedom; cultural identity }\end{array}$ & $\begin{array}{l}\text { In addition, to provide } \\
\text { money for education, } \\
\text { cultivation, house building. } \\
\text { Fewer livestock, focusing on } \\
\text { high-quality breeds. }\end{array}$ & $\begin{array}{l}\text { Specifically for milk for the } \\
\text { family; to sell for food and } \\
\text { clothes }\end{array}$ & $\begin{array}{l}\text { Emphasise milk for } \\
\text { children and health. }\end{array}$ \\
\hline House & Shelter, comfort, to raise a family & $\begin{array}{l}\text { Aspire to a modern concrete } \\
\text { house }\end{array}$ & No mention of aspirations & $\begin{array}{l}\text { For warmth, less need for } \\
\text { firewood and to rebuild }\end{array}$ \\
\hline Private land & $\begin{array}{l}\text { For housing, cultivation, and } \\
\text { olekeri; to provide security }\end{array}$ & $\begin{array}{l}\text { To have authority to make } \\
\text { own decisions about land } \\
\text { use }\end{array}$ & $\begin{array}{l}\text { Some concerns regarding } \\
\text { land conflict }\end{array}$ & -- \\
\hline Communal land & $\begin{array}{l}\text { Seasonal movement of livestock } \\
\text { and during droughts. }\end{array}$ & -- & -- & -- \\
\hline Access to services & $\begin{array}{l}\text { Water, health, education, } \\
\text { veterinary, and material goods }\end{array}$ & -- & $\begin{array}{l}\text { Veterinary, market for } \\
\text { livestock }\end{array}$ & $\begin{array}{l}\text { Emphasis on health and } \\
\text { water, education }\end{array}$ \\
\hline Agricultural production & $\begin{array}{l}\text { Production of own food; sense of } \\
\text { security; secures land }\end{array}$ & -- & $\begin{array}{l}\text { Concerns about } \\
\text { unpredictability and } \\
\text { unfamiliarity }\end{array}$ & $\begin{array}{l}\text { Money for food and } \\
\text { hospital costs; to avoid } \\
\text { selling livestock }\end{array}$ \\
\hline Children & Labor, social structure & Tend to want fewer & -- & $\begin{array}{l}\text { For pride; importance of } \\
\text { boys }\end{array}$ \\
\hline Education for children & $\begin{array}{l}\text { Land security, productivity of } \\
\text { livestock and agriculture; regain } \\
\text { advantage against outsiders }\end{array}$ & $\begin{array}{l}\text { To compete in the modern } \\
\text { world; important for girls as } \\
\text { well as boys }\end{array}$ & $\begin{array}{l}\text { See less value in girls } \\
\text { education as will join } \\
\text { husband's family; trade- } \\
\text { offs with tradition }\end{array}$ & $\begin{array}{l}\text { Emphasized importance } \\
\text { for girls; to help the family }\end{array}$ \\
\hline Transport (motorbike) & $\begin{array}{l}\text { Makes communication and trade } \\
\text { easier }\end{array}$ & Emphasized by this group & -- & No mention \\
\hline Source of income & $\begin{array}{l}\text { To provide freedom for women; } \\
\text { rarely mentioned directly by men }\end{array}$ & -- & Trade-offs with tradition & $\begin{array}{l}\text { Independence and } \\
\text { authority; to buy items not } \\
\text { considered important by } \\
\text { men }\end{array}$ \\
\hline \multicolumn{5}{|l|}{ Relational } \\
\hline Social unity & $\begin{array}{l}\text { Subjective well-being, helping } \\
\text { those in need including } \\
\text { restocking }\end{array}$ & -- & -- & $\begin{array}{l}\text { Maintains peace; mutual } \\
\text { assistance, e.g., sharing } \\
\text { food, caring for sick }\end{array}$ \\
\hline Cultural traditions & Identity, social stability, unity & $\begin{array}{l}\text { Value some traditions } \\
\text { including clan and age } \\
\text { structures }\end{array}$ & $\begin{array}{l}\text { Most concerned about } \\
\text { continuity and loss }\end{array}$ & Linked to social unity \\
\hline $\begin{array}{l}\text { Having a voice in } \\
\text { decisions }\end{array}$ & A sense of agency and security & Mostly related to $p$ & rotection of land & $\begin{array}{l}\text { Mostly related to domestic } \\
\text { sphere }\end{array}$ \\
\hline Autonomy & Linked to security & Provided throu & sh private land & $\begin{array}{l}\text { Economic freedom, } \\
\text { through ability to earn } \\
\text { and keep income }\end{array}$ \\
\hline \multicolumn{5}{|l|}{ Subjective } \\
\hline A sense of security & All focus on land security & $\begin{array}{l}\text { Through education for } \\
\text { children }\end{array}$ & $\begin{array}{l}\text { Partially through cultural } \\
\text { continuity }\end{array}$ & $\begin{array}{l}\text { Through education for } \\
\text { children }\end{array}$ \\
\hline
\end{tabular}

Communal grazing land is important but youneed private land so you can make your own decisions about what to use it for ... if it is communal anyone can from outside and take it. (Korianga, junior elder, Loiborsoit village)

Having authority or individual control over land is particularly important to young men, showing a shift toward individual or household ownership from collective decision making about land management. However, all male participants recognized the importance of shared grazing lands because of the seasonal movements of cattle to pasture and for access to resources during droughts. The restrictions and private nature of agricultural land is thought to be unequitable by some:
In the past there was no private land. The only place set aside was for calves. The other areas were for everyone. Now there is private allocation. I think having communal land is important so people can use it equally and it is not restrictive like private land. (Esuri, retired elder, Terrat village)

Some men view agriculture more generally as incompatible with a pastoralist way of life and the cause of community conflict. With reference to this conflict and subjective well-being, one man reflected: 
Our eyes like to see pasture not cultivation; it has destroyed the nature of the land and many problems can come from it. We farm because of hunger, we don't feel we should do it. It feels better to see grazing land. (Makaa, senior elder, Loiborsoit village)

Agriculture is seen by some, especially older men and those in Terrat and Sukuro, as unfamiliar and unpredictable:

I prefer livestock keeping. It is familiar to us, we have confidence in doing it, and we can go far with it. Hunger has pushed us into agriculture. The conditions for it depend on luck. (Makaa, senior elder, Terrat village)

Discussions about the future centered on concerns and fears about land security. Threats to land are seen to come from population growth (and associated perceived increases in livestock), outsiders including Maasai moving in, investors and the leasing of land, and conservation. There is an increasing problem of households leasing or selling ${ }^{[5]}$ their land rather than cultivating it themselves, with reports of clandestine land grabs. There was high levels of mistrust toward outsiders who come in through associations with the church, development interventions, research, and conservation, but are thought to have ulterior motives. Men expressed a lack of power and voice in these processes, and felt disadvantaged because of a lack of education in relation to other groups.

People from outside come to invest, but they really want to take a piece of land. They may say something but actually do another thing. Conservation is also like this. (Landis, senior elder, Loiborsoit village)

Conservation, via government and NGOs, was often grouped together with other threats. In particular there was a worry about Wildlife Management Areas being implemented in Simanjiro, and that Tarangire National Park will be extended, resulting in not only land losses but increased impacts of wildlife on agriculture and livestock. The government is viewed as prioritizing conservation, with politicians able to make sudden decisions outside of people's control. Men expressed a sense of injustice about the historical loss of land, continued infringements, and lack of compromise, for example during the droughts in 2009, when many herders took their livestock toward the park:

Even though we share our land with wildlife, they cannot share the area with our livestock. (Landis, senior elder, Loiborsoit village)

Men aimed to improve security through a variety of means, including agriculture, securing tenure, and through education of young people. Younger men generally see formal education as more desirable and unproblematic than the older generations, and were more likely to mention the value of education for girls as well as for boys. Positive views about education were expressed in the interviews, but many older men remained sceptical about the benefits it would ultimately bring, seeing unavoidable trade-offs with some traditions. Overall education is considered necessary to face the challenges and complexities of the modern world and to progress. In particular the ability to read information and land contracts, and understand hidden agendas of external actors are viewed as important to protect Maasai land, to get benefits from wildlife, and to improve productivity of livestock and agriculture.
Men expressed feelings of disadvantage in their interactions with other groups, and threats from outsiders who are able to use their education to "steal our land by the pen."

\section{It [education] will help to protect the land, together with the government. People are thinking about how to take our land away. If there are educated people in the community, they will have the knowledge to stop this. They can see whether we can trust people. (Landis, senior elder, Emboreet village)}

Although relational aspects of well-being were not directly discussed as much by men as by women (see below), peace was presented as being a foundation for aspects of material well-being and important for feeling good. Otherwise, the importance of social unity (enaiboshu) was discussed in terms of helping others in need within the community, especially ewoloto, the practice of restocking destitute households within clans with livestock. However, many men across villages talked of their concern about increasing amounts of conflict within and between villages stemming from land privatization, development interventions, party politics, and poor and corrupt leadership. Subjective wellbeing experiences are shaped by cultural norms and values, which are clearly shifting among the Maasai of the region, and were a source of debate during interviews. All men recognized that some traditions were important and a "source of community" as one man put it. All agreed that the age-set system was critical in creating systems of respect and knowledge sharing across generations. As in the case of the shift away from pastoralism, which in itself forms a central core of cultural identity, some older men are clearly uneasy about the rate of change to cultural traditions that was attributed to economic development, links with outsiders, formal education, and the Christian church. In a rare instance of men raising the issue of money directly, men of the older generations (Makaa and Seuri age-sets) in Loibosoit, blamed, among other factors, the monetary economy for the decline in traditions and women's increasing independence.

\section{If I could take Maasai back to the way we were I would be happy. (Makaa, senior elder, Loiborsoit village)}

Younger men are more ready to embrace change, but emphasized that some traditions did not complement their modern aspirations to be educated, equal to other social groups and part of a diversified economy. Many men (largely of the two youngest agesets) were clear that some traditions were no longer beneficial to Maasai society. This included esoto (the practice of dancing, flirtation, and sexual activity between warriors [ilmurran] and young uncircumcised girls), which appears to have ceased or been pared back since Korianga were circumcised, and was deemed a waste of time and interfered with education. Concerns were also raised about laibons (ritual leaders in Maasai society) becoming corrupted by wealth and a source of community conflict.

\section{Components of well-being for women}

There were many similarities between men and women's views but some significant differences emerged as to aspects of their lives that women valued and the reasons provided (Table 2). No particular patterns emerged in the ideas put forward by women according to age. As for men, having children is vital for having a good life. Women emphasized living among their children and the pride they feel in them. Some women mentioned the 
importance of having a boy for their own security, because the traditional inheritance system means that once they are beyond reproductive age, women go to live with a son and his family. Women also consider education important for two reasons: to bring "positive change" and security to the village, family, and themselves by gaining employment in professional jobs such as medicine and teaching; and second, to understand the value of land and to ensure its security. Women emphasized the value of girl's education as a means of gaining independence. Livestock are also a key aspect of a good life, primarily to ensure the children have milk for health. The ability to access services is, as for the men, a priority, but the emphasis for women was on healthcare (dispensaries and clinics in the villages and the ability to get to a hospital), and water resources. Many women mentioned having a warm, modern, and secure house, because it would require less firewood to heat and time to rebuild, which is a women's responsibility.

Women expressed more concern than men about livelihoods and food security.

I worry about hunger ... if there is not enough rain for agriculture. We don't know what is going to happen, we can only wait for God to show us. (Endasati middle-aged woman, Sukuro village)

Women were just as concerned as men about land security and threats from external actors who cannot be trusted and "take things away from us and we are given nothing in return." Agriculture, in addition to providing food directly for the household, is important to women for income, either through selling crops from their own household or working on other people's farms. In fact, money was raised as a contributor to wellbeing far more by women (a total of 19 separate instances across the interviews) as opposed to men (only 3 instances). Communal land is also considered important especially for dry season grazing but was often not mentioned at all.

Relational aspects of well-being were discussed far more in the women's interviews than in the men's (36 separate instances compared with 17 for men). Women expressed the importance of good relationships between husband and wife, including being treated equally to other wives (first wives tend to have authority over other wives), gaining respect, and being listened to. Within the homestead, living harmoniously among other wives is considered important for peace of mind. The tradition of unity (enaiboshu) of the Maasai cultural group overall is viewed as important for mutual assistance in times of need (sharing food and helping neighbors when they are sick for instance), to create peace, and for subjective well-being (feeling good from celebrations, sharing food and ideas with neighbors). Conflict is perceived to arise because of people attempting to realize the value of land, leasing land, through boundary conflicts, and more generally through a rise in individualism and inequity because some people have become wealthy through Tanzanite mining or other enterprises. Women discussed how conflict was often directly between men but women would still suffer through unrest in the homestead.

Having a voice in decisions made about livelihoods, children's education in the home, and in the wider community was discussed as important and lacking in women's lives in all the interviews.
Women linked having a voice to economic independence in a mutually reinforcing way.

Most Maasai women do not have any sound to speak
with, and no property. When we want to go to hospital
we have no voice to speak in front of our husbands and
no ability to sell cows to pay for the hospital. (Endasati
middle-aged woman, Loiborsoit village)

Economic independence, through owning land, livestock, selling products, and even having a bank account, was an aspiration for many women (16 women discussed this). For some, the expansion in economic opportunities, such as through earning money working on other people's farms or through selling excess milk to neighbours, had allowed them to achieve this aim to some extent. However, having the autonomy to use the money themselves is dependent on the nature of their relationship with their husbands who "can give me a voice." Exerting agency via economic activities was seen by women as the most direct means of empowerment and authority (engidimata). In a practical sense it allows women to buy domestic and educational items that men do not readily provide such as school resources (uniforms, pens, books), clothes, and kitchen utensils, as well as to send children to school. There are various NGO, government, and self-initiated women's groups centered on economic activities such as savings and loans, and small-livestock holdings that are enabling women to earn their own money. For some, who cannot keep the money they earned due to their domestic situation, the wider range of economic activities women are involved in through agriculture is just a continuation of the labor burden and unequal access to resources: "Women harvest and the men take the harvest."

Women associated Maasai tradition and the past overall with women being poorly treated, beaten, overworked, not listened to, and largely treated as children. Unlike men, women had no debate about how positive social and cultural changes over the last few decades had been. These changes, which have involved women being given "responsibility" and "individual rights," were largely attributed to the Christian church, but also education and the government. The church is a big part of women's lives, and was presented in a purely positive way as an institution that has given women a "right to speak," a role, and has reduced conflict generated by land privatization and inequity. Like men, women viewed some traditions such as esoto and laibons as outdated, with the addition that some suggested that female circumcision and the early marriage of girls, practices that have been targeted by government and NGO campaigns, should stop.

\section{Differences between villages}

In villages not adjacent to Tarangire National Park (Sukuro and Terrat) that have a smaller area of village land and agriculture has less of an established history, the importance of communal grazing land was emphasized and men more readily expressed wariness about shifting to agriculture. In these villages, men discussed the insufficiency in terms of space and flexibility of private lands for agropastoral livelihoods. They highlighted the role of communal land in social equity, links to social institutions ("we need village land as we are one community") and for flexibility in seasonal movement of livestock and during periods of drought. The only place where men suggested that private land should be used for grazing was in Emboreet village. Being near the boundary of Tarangire National Park, in Emboreet, men were 
concerned that cultivation of private land was limited by wildlife, making it difficult to guard more than 10 acres for any one household. Men and women in Emboreet and Loibosoit (also adjacent to the Park) more readily expressed their sense of injustice from conservation in that they were negatively affected by wildlife but did not receive benefits, although men across all villages mentioned the concern they felt about the Park expanding in the future.

\section{DISCUSSION}

\section{Diversity and change in Maasai well-being conceptions}

We identified several differences between age-sets in men's ideas about well-being, the significant divide being between Korianga (who have recently become junior elders) and the older age-sets. Korianga are the first generation to find significant sources of wealth through involvement in Tanzanite mining, and migration to urban areas, exposing them to new sources of knowledge, ideas, and technology (Baird and Hartter 2017). This represents a significant shift within the wider changes in dominant ideas of Maasai masculinity throughout the last century, in which the agesets remain an organizing structure of social relations but the experiences and attitudes of the age-sets change (Hodgson 2001). This shift has possible implications for continuation of the pastoral system and therefore communal land management more compatible with conservation aims. The consequences are potentially contradictory: on the one hand young men are focused on agriculture, livelihood diversity, material goods, and individual autonomy but they also want smaller families implying slower population growth in the future. For older men, the cultural meaning associated with pastoralism and traditions is stronger, so a sense of loss of these is impacting on subjective well-being. This highlights the socially constructed meaning in experiences of well-being; older men are experiencing the material and social changes in a different way to younger. As in all social groups, ideas about well-being are being negotiated, as traditional and new identities meet. The outcomes of this process for pastoralism and fragmentation of the rangelands are uncertain, especially because, as Lesorogol and Boone (2016) also found for Samburu, the preferences for private, agricultural land versus communal, grazing land in young and older men, respectively, are not absolute and vary.

Women focused more on the relational aspects of their lives than men in discussions on well-being. This is perhaps unsurprising, given that women are often in the position of lesser power in their interactions at different scales, and therefore have more to gain and lose from their relationships. Cultural norms form the basis of high levels of gender inequality in Maasai society in which women remain in a subordinate position although with variation across levels of education, wealth, and age (Hodgson 1999). Livelihood diversification is, however, providing women with opportunities to take on new roles and gain a degree of economic independence and power (Brockington 2001). Many women we interviewed aspired to start, or had already started their own small businesses to be in control of their own money, primarily as a means of gaining authority within their household and beyond, pointing to freedom as a fundamental foundation of well-being. Selling products on local markets is accepted by men for the most part because it contributes to the household economy, but is unlikely to be transformational with respect to power structures
(Smith 2014). These activities could form an incremental step within processes of empowerment, in which resources (material, relational, and knowledge) are being used by Maasai women to take control of their lives, make decisions, and in doing so challenge gender norms (Goldman and Little 2015). However, the ability of women to take part in new employment opportunities and importantly to control the income they earn, remains constrained by their relationships with their husbands. Thus a women's ability to achieve her well-being goals is likely to be defined not only by gender, but in turn by her and her husband's age and status, social connections and education. The shifts in gender norms created by the opening up of economic opportunities and socio-cultural changes through NGO interventions, the Christian church, and education are being resisted by some men, especially of the older generation. Policy and interventions that involve or target women can impact on social dynamics and conflict (Devereux et al. 2013), highlighting the need to be sensitive to cultural norms and fine-scaled relationships. As Hodgson (2001) has argued, without this sensitivity, external interventions can ignore aspects of women's power and add weight to gender inequalities. Certainly there may be trade-offs resulting from livelihood changes, where power and resources are gained in one respect to be lost in another (Wangui 2008). Here, the increase in labor that comes with new agricultural activities, was highlighted by some women as a cost. The particular concern women expressed about livelihood security results from their lack of power in decision making and that they are at the frontline of household duties and the everyday realities of feeding and clothing children. The fact that women can be left in precarious positions through circumstance, e.g., becoming a widow or leaving an abusive husband, forces many to focus on personal material security to the exclusion of broader aspirations.

The variation in well-being conceptions between the villages has implications for a landscape level approach to conservation encompassing protection or sustainable use of areas outside formally protected areas. Some differences in ideas emerged between villages adjacent to the park, and those further away with people in Emboreet and Loiborsoit (adjacent) more focused on agriculture. This reflects previous work suggesting that land conversion to agriculture and livelihood diversification is influenced by proximity to the park because of perceived threat of park expansion (Sachedina 2008, Baird et al. 2009). It also reflects village level decisions regarding land use allocation in Emboreet and Loiborsoit where the village administration has promoted cultivation and resisted conservation on the plains where wildlife migrate from TNP in the wet season (Leslie and McCabe 2013). These fine-scaled differences can have large effects on conservation strategies. The conservation easement in two of the villages, by targeting the intersecting concerns of land security, access to grazing, and trust, provides one promising model of conservation (Nelson et al. 2010), but is constrained by the conflicting priorities of villages bordering the park that would allow the creation of a continuous corridor through the plains.

Implications for the incorporation of well-being into conservation policy and practice

How a problem is framed shapes the choices made in conservation interventions. Using the concept of well-being as a research framework provides a way to engage holistically with the realities of people's lives in a way that is meaningful to them. We suggest 
that a broad, multidimensional, locally driven, and disaggregated well-being perspective can elucidate connections between ecosystems and human development, and reshape the design, objectives, and evaluation of interventions toward a more socially just conservation. There is an increasing focus on equity (or more broadly justice) in conservation, with the Aichi targets of the Convention on Biological Diversity (CBD) aiming for protected areas that are "effectively and equitably managed." Equity or justice is conceptualized in three areas of concern: (i) distribution of costs and benefits from conservation; (ii) procedure referring to participation in decision making; (iii) recognition of social and cultural difference (Schlosberg 2013). Well-being, centered on people's capabilities to a live a life considered worthwhile, can be seen as the ultimate measure of justice (Edwards et al. 2016), and forms a critical foundation for inquiries regarding injustices as well as a showing the outcomes of more or less just activities. Efforts to establish approaches and indicators for assessing justice in conservation (Dawson et al. 2017, Zafra-Calvo et al. 2017) should therefore be complemented by well-being inquiry. Moreover, a multidimensional vision of well-being driven by local perspectives should feature more prominently in conservation policy; for example, it is central to rights-based approaches that include the "right to development" (Springer and Campese 2011). Last, we reflect on what our approach and results suggest for how well-being should be incorporated into conservation policy and practice that takes social justice seriously.

Conservation research and practice continues to privilege objective material well-being, such as income and assets (Halpern et al. 2013, de Lange et al. 2016), while tending to use stand-alone quantitative indicators for impact evaluations. Our study suggests material assets, namely land and livestock, remain an essential need in Maasai society, but also represent a means to other ends, showing how the material dimension of well-being is fundamentally intertwined with relational and subjective aspects. Owning cattle provides a sense of dignity, status, and a means of achieving freedom and security. Money itself was not expressed as being of primary importance, especially for men. Conservation policy often emphasizes income and livelihoods as a means of reducing pressure on resources and compensating people for the costs of conservation but livelihoods go far beyond material importance to being a way of life with cultural and social significance. In Simanjiro, there remains strong commitment to a pastoralist way of life in that people want large herds and access to communal land, but livelihoods have diversified over the last four decades. Conservation narratives and policy emphasize the problem of farming in the "wildlife corridor," and pastoralism, in contrast with historical colonial views, is now seen as compatible with conservation aims (Goldman 2003). As much as external representations of Maasai focus on nomadic and pastoralist identity, agriculture is undeniably an important part of people's way of life and well-being and has become established as a social norm, essential for dignity (McCabe et al. 2010) suggesting conservation strategies will need to accommodate these needs. Although Table 2 may suggest that we can clearly delineate components of well-being, the overlapping nature of the three dimensions of well-being mean that studying one aspect in isolation or developing stand-alone indicators is not enough (McGregor and Sumner 2010). The development of indicators is useful in measuring progress but should be contextualized in and complemented by qualitative understandings of reasons for importance of the well-being component, processes of well-being change, and relationships between aspects of well-being (Woodhouse et al. 2015). Indicators across the dimensions for impact evaluation should be tailored to subjective conceptions of well-being.

Conservation is not simply a technical endeavour but fundamentally a social and political process that can transform institutional arrangements and power relations (Brechin et al. 2002), affecting relational and subjective well-being. Subjective well-being in Simanjiro is centered on a sense of security about the future and being able to adapt to change. These feelings are very much based in historical and continuing instances of land and resource alienation in Simanjiro and across Maasailand, and exacerbated in communities adjacent to Tarangire NP. In this way, current subjective well-being is affected by future perceived wellbeing and based in historical injustices, emphasizing the temporal dynamics of well-being (McGregor 2007). This sense of insecurity is shaping priorities for other aspects of well-being identified, namely ownership of private land, agricultural production, and education, with implications for conservation. Pastoralists are adept at coping with resource variability through flexibility and mobility. Fragmentation, alongside the diverse and changing perceived threats from investors and conservation, and the lack of trust that has been generated, are creating high levels of uncertainty for people. A sustained sense of security is fundamentally linked to autonomy, the ability to make your own choices (Wood 2007), and this was highlighted by all social groups, and again was prioritized in those villages nearest the park. This brings to the fore the idea at the center of the capabilities approach and the importance of attention to the procedural dimension of justice: human freedom and the ability to make decisions affecting one's life are fundamental to human dignity and well-being. Even if material needs are met, attempts to impose conservation policy from the top down without addressing security concerns, allowing local autonomy, and building trust, will undoubtedly be resisted especially in the context of deep-rooted historical injustices and continuing threats to land.

The standard capabilities approach to well-being and justice takes a liberal philosophical stance that focuses on harms to individuals, but here relational well-being extended to social unity and cultural continuity suggesting attention to community level impacts from conservation is needed in measures of change. Men and women both value social unity and some reflected on the breakdown in social capital, which was linked in part to land privatization, increased wealth for some due to greater economic opportunities, and cultural trends toward individualism. The connection between individual and collective well-being is shaped by dynamic institutions, e.g., norms that can be impacted by social change, including from conservation interventions. Research suggests that diversified livelihoods and reduced mobility have increased wealth stratification in Maasai communities (Homewood et al. 2009) reducing and altering the nature of traditional reciprocal exchange such as restocking and gift-giving (Baird and Gray 2014). Land fragmentation resulting from protected areas and exacerbated by the rise of agriculture, has been implicated in reshaping Maasai notions of landscape from a fluid mosaic to a divided and individualized landscape governed by unequal power relations (Goldman 2003). Some people in Simanjiro, were 
conscious of and concerned by these changes. Others were pragmatic, or represented changing cultural norms in ideas of relational well-being and its connection to the collective governance of resources. The diversity of viewpoints is likely to reflect wealth inequalities and livelihood strategies between households, as well as different development pathways across villages. Some households with sufficient labor and money, social connections and knowledge can perhaps "reach beyond the constraints of fragmentation" to find new ways of coping under a changing environment, e.g., during droughts (Goldman and Riosmena 2013). However, in the face of shocks from climate change, land grabs, and market changes, these individualist land use strategies may reduce the ability for collective action and ultimately produce long-term vulnerability of the socialecological system as a whole (Galvin 2009). This suggests the importance of including collective well-being and broader societal goals more likely to benefit the most marginalized in conservation planning and measures of impacts. In this case, decisions will hinge on balancing the degree of land enclosure and privatization with shared management of grazing lands.

Understanding how communities that are impacted by conservation define well-being will be crucial in assessment of the distribution of well-being benefits and burdens, and in efforts to create more equitable conservation that respects locally defined fairness principles and mitigates or compensates costs in acceptable ways. There is a growing acceptance that there will always be winners and losers from conservation, and trade-offs between different outcomes (Hirsch et al. 2010). Locally grounded well-being research as described here provides a starting point for the recognition of cultural values and knowledge in more just approaches to conservation. However, to view people only through the lens of a singular ethnic identity is problematic because identities are complex and constantly evolving (e.g., Sullivan 2002). The diversity in values, priorities, and aspirations we found across men and women, age-sets, and villages with differing levels of conservation impact, shows the importance of taking a disaggregated approach to well-being analyses within one cultural setting. Benefits and burdens should be conceptualized in terms of range of well-being components important to different groups, ensuring the priorities of the most marginalized groups are represented. As the primary owners of land and livestock, men remain in a position of power regarding material resources. This can mean that the impacts of policies on women are invisible, if concerted efforts to understand their priorities and hear their experiences are not made. Reaching a more just approach to land management and conservation will involve deliberation between different stakeholders who will have different well-being priorities as well as principles of fairness. This involves making explicit, negotiating, and seeking to minimize the inevitable trade-offs between all aspects of human well-being and conservation, at different spatial and temporal scales, which are understood and experienced in different ways by different people (McShane et al. 2011). As highlighted in this case study, rapidly changing socioeconomic contexts and configurations of interests that coevolve with well-being conceptions and aspirations call for adaptive management systems including ongoing dialogue with communities impacted by conservation.
${ }^{[1]}$ Wildlife Management Areas (WMAs) were originally conceived as part of Tanzania's strategy to devolve wildlife management decisions and benefits to local communities. Since 2007, however, the state has formalized central control of licences for game viewing and hunting enterprises in WMAs.

${ }^{[2]} \mathrm{A}$ woman does not belong to an age-set but is aligned with the age-set of her husband when she marries him. We used common categories based on key life phases, e.g., marriage and childbirth more relevant to a women's social role, and therefore their wellbeing.

${ }^{[3]}$ Dorobo is an umbrella term for hunter-gatherers of the region, and for Maasai refers to people who have no livestock.

[4] Maasai houses of the region are now largely built in the "Arusha" style, constructed of timber poles and branches plastered with mud and cow dung, with thatched roofs.

${ }^{[5]}$ Although land sales are illegal we have heard of individuals from outside the area arranging to purchase land even though no title deeds are obtained.

Responses to this article can be read online at: http://www.ecologyandsociety.org/issues/responses. $\mathrm{php} / 9986$

\section{Acknowledgments:}

This research was funded by the ESRC-DFID joint fund for poverty alleviation (ES/J018155/1). We would like to thank our field assistants Isaya Rumas, Gabriel Ole Saitoti, and Rebecca Kilakoy.

\section{LITERATURE CITED}

Abunge, C., S. Coulthard, and T. M. Daw. 2013. Connecting marine ecosystem services to human well-being: insights from participatory well-being assessment in Kenya. Ambio 42 (8):1010-1021. http://dx.doi.org/10.1007/s13280-013-0456-9

Baird, T. D. 2014. Conservation and unscripted development: proximity to park associated with development and financial diversity. Ecology and Society 19(1):4. http://dx.doi.org/10.5751/ ES-06184-190104

Baird, T. D., and C. L. Gray. 2014. Livelihood diversification and shifting social networks of exchange: a social network transition? World Development 60:14-30. http://dx.doi.org/10.1016/j. worlddev.2014.02.002

Baird, T. D., and J. Hartter. 2017. Livelihood diversification, mobile phones and information diversity in Northern Tanzania. Land Use Policy 67:460-471. http://dx.doi.org/10.1016/j. landusepol.2017.05.031

Baird, T. D., P. W. Leslie, and J. T. McCabe. 2009. The effect of wildlife conservation on local perceptions of risk and behavioral response. Human Ecology 37(4):463-474. http://dx.doi.org/10.1007/ s10745-009-9264-Z

Benjaminsen, T. A., M. J. Goldman, M. Y. Minwary, and F. P. Maganga. 2013. Wildlife management in Tanzania: state control, rent seeking and community resistance. Development and Change 44(5):1087-1109. http://dx.doi.org/10.1111/dech.12055 
Bluwstein, J., F. Moyo, and R. P. Kicheleri. 2016. Austere conservation: understanding conflicts over resource governance in Tanzanian wildlife management areas. Conservation and Society 14(3):218-231. http://dx.doi.org/10.4103/0972-4923.191156

Brechin, S. R., P. R. Wilshusen, C. L. Fortwangler, and P. C. West. 2002. Beyond the square wheel : toward a more comprehensive understanding of biodiversity conservation as social and political process. Society and Natural Resources 15:41-64. http://dx.doi. org/10.1080/089419202317174011

Brockington, D. 2001. Women's income and the livelihood strategies of dispossessed pastoralists near the Mkomazi Game Reserve, Tanzania. Human Ecology 29(3):307-338. http://dx.doi. org/10.1023/A:1010906715682

Brockington, D. 2004. Community conservation, inequality and injustice: myths of power in protected area management. Conservation and Society 2:411-422.

BurnSilver, S. B. 2007. Pathways of continuity and change: diversification, intensification and mobility in Maasailand, Kenya. Dissertation. Colorado State University, Fort Collins, Colorado, USA.

Buzinde, C. N., J. M. Kalavar, and K. Melubo. 2014. Tourism and community well-being: the case of the Maasai in Tanzania. Annals of Tourism Research 44:20-35. http://dx.doi.org/10.1016/j. annals.2013.08.010

Cetas, E. R., and M. Yasué. 2016. A systematic review of motivational values and conservation success in and around protected areas. Conservation Biology 31:203-212. http://dx.doi. org/10.1111/cobi. 12770

Coulthard, S., D. Johnson, and J. A. McGregor. 2011. Poverty, sustainability and human wellbeing: a social wellbeing approach to the global fisheries crisis. Global Environmental Change 21 (2):453-463. http://dx.doi.org/10.1016/j.gloenvcha.2011.01.003

Davis, A. 2011. 'Ha! What is the benefit of living next to the park? ' Factors limiting in-migration next to Tarangire National Park, Tanzania. Conservation and Society 9(1):25-34. http://dx.doi. org/10.4103/0972-4923.79184

Daw, T., K. Brown, S. Rosendo, and R. Pomeroy. 2011. Applying the ecosystem services concept to poverty alleviation: the need to disaggregate human well-being. Environmental Conservation 38 (4):370-379. http://dx.doi.org/10.1017/S0376892911000506

Dawson, N., and A. Martin. 2015. Assessing the contribution of ecosystem services to human wellbeing: a disaggregated study in western Rwanda. Ecological Economics 117:62-72. http://dx.doi. org/10.1016/j.ecolecon.2015.06.018

Dawson, N., A. Martin, and F. Danielsen. 2017. Assessing equity in protected area governance: approaches to promote just and effective conservation. Conservation Letters http://dx.doi. org/10.1111/conl.12388

de Lange, E., E. Woodhouse, and E. J. Milner-Gulland. 2016. Approaches used to evaluate the social impacts of protected areas. Conservation Letters 9:327-333. http://dx.doi.org/10.1111/ conl.12223
Deneulin, S., and J. A. McGregor. 2010. The capability approach and the politics of a social conception of wellbeing. European Journal of Social Theory 13(4):501-519. http://dx.doi. org/10.1177/1368431010382762

Devereux, S., K. Roelen, C. Béné, D. Chopra, J. Leavy, and J. A. McGregor. 2013. Evaluating outside the box: an alternative framework for analysing social protection programmes. Institute of Development Studies, Brighton, UK. http://dx.doi. org/10.1111/j.2040-0209.2013.00431.x

Edwards, G. A. S., L. Reid, and C. Hunter. 2016. Environmental justice, capabilities, and the theorization of well-being. Progress in Human Geography 40(6):754-769. http://dx.doi. org/10.1177/0309132515620850

Fratkin, E. 2001. East African pastoralism in transition: Maasai, Boran, and Rendille cases. African Studies Review 44(3):1-25. http://dx.doi.org/10.2307/525591

Galvin, K. A. 2009. Transitions: pastoralists living with change. Annual Review of Anthropology 38(1):185-198. http://dx.doi. org/10.1146/annurev-anthro-091908-164442

Gardner, B. 2016. Selling the Serengeti: the cultural politics of safari tourism. University of Georgia Press, Athens, Georgia, USA.

Gereta, E., G. E. O. Meing'ataki, S. Mduma, and E. Wolanski. 2004. The role of wetlands in wildlife migration in the Tarangire ecosystem, Tanzania. Wetlands Ecology and Management 12 (4):285-299. http://dx.doi.org/10.1007/s11273-005-3499-2

Goldman, M. 2003. Partitioned nature, privileged knowledge: community-based conservation in Tanzania. Development and Change 34(5):833-862. http://dx.doi.org/10.1111/j.1467-7660.2003.00331. $\underline{\mathrm{x}}$

Goldman, M. J. 2011. Strangers in their own land: Maasai and wildlife conservation in Northern Tanzania. Conservation and Society 9(1):65-79. http://dx.doi.org/10.4103/0972-4923.79194

Goldman, M. J., and J. S. Little. 2015. Innovative grassroots NGOs and the complex processes of women's empowerment: an empirical investigation from Northern Tanzania. World Development 66:762-777. http://dx.doi.org/10.1016/j.worlddev.2014.09.005

Goldman, M. J., and F. Riosmena. 2013. Adaptive capacity in Tanzanian Maasailand: changing strategies to cope with drought in fragmented landscapes. Global Environmental Change 23 (3):588-597. http://dx.doi.org/10.1016/j.gloenvcha.2013.02.010

Halpern, B. S., C. J. Klein, C. J. Brown, M. Beger, H. S. Grantham, S. Mangubhai, M. Ruckelshaus, V. J. Tulloch, M. Watts, C. White, and H. P. Possingham. 2013. Achieving the triple bottom line in the face of inherent trade-offs among social equity, economic return, and conservation. Proceedings of the National Academy of Sciences of the United States of America 110(15):6229-6234. http://dx.doi.org/10.1073/pnas.1217689110

Hirsch, P. D., W. M. Adams, J. P. Brosius, A. Zia, N. Bariola, and J. L. Dammert. 2010. Acknowledging conservation trade-offs and embracing complexity. Conservation Biology 25(2):259-264. https://doi.org/10.1111/j.1523-1739.2010.01608.x 
Hodgson, D. L. 1999. Women as children: culture, political economy, and gender inequality among Kisonko Maasai. Nomadic Peoples 3(2):115-130. http://dx.doi.org/10.3167/082279499782409451

Hodgson, D. L. 2001. Once intrepid warriors: gender, ethnicity, and the cultural politics of Maasai development. Indiana University Press, Bloomington, Indiana, USA.

Homewood, K. M. 2008. Ecology of African pastoralist societies. James Currey, Oxford, UK.

Homewood, K. M., P. Kristjanson, and P. Chenevix Trench. 2009. Staying Maasai? Livelihoods, conservation and development in East African Rangelands. Springer, New York, New York, USA.

Igoe, J. 2010. The spectacle of nature in the global economy of appearances: anthropological engagements with the spectacular mediations of transnational conservation. Critique of Anthropology 30(4):375-397. http://dx.doi.org/10.1177/0308275$\underline{\mathrm{X} 10372468}$

Igoe, J., and D. Brockington. 1999. Pastoral land tenure and community conservation: a case study from North-east Tanzania. Pastoral Land Tenure Series, No 11. International Institute for Environment and Development, London, UK.

Igoe, J., and B. Croucher. 2007. Conservation, commerce and communities: the story of community-based Wildlife Management Areas in Tanzania's northern tourist circuit. Conservation and Society 5(4):534-561.

Leslie, P., and J. T. McCabe. 2013. Response diversity and resilience in social-ecological systems. Current Anthropology 54 (2):114-143. http://dx.doi.org/10.1086/669563

Lesorogol, C. K., and R. B. Boone. 2016. Which way forward? Using simulation models and ethnography to understand changing livelihoods among Kenyan pastoralists in a "new commons." International Journal of the Commons 10(2):747-770. http://dx.doi.org/10.18352/ijc.656

Little, P. D., K. Smith, B. A. Cellarius, D. L. Coppock, and C. B. Barrett. 2001. Avoiding disaster: diversification and risk management among East African herders. Development and Change 32(3):401-433. http://dx.doi.org/10.1111/1467-7660.00211

Martin, A., N. Gross-Camp, B. Kebede, S. McGuire, and J. Munyarukaza. 2014. Whose environmental justice? Exploring local and global perspectives in a payments for ecosystem services scheme in Rwanda. Geoforum 54:167-177. http://dx.doi. org/10.1016/j.geoforum.2013.02.006

Mathews, G., and C. Izquierdo. 2009. Introduction: anthropology, happiness, and well-being. Pages 1-19 in G. Mathews and C. Izquierdo, editors. Pursuits of happiness: wellbeing in anthropological perspective. Berghahn Books, New York, USA.

McCabe, J. T. 2002. Conservation with a human face? Lessons from 40 years of combining conservation and development in the Ngorongoro Conservation Area, Tanzania. Pages 61-76 in D. Chatty, editor. Displacement, forced settlement and conservation. Berghahn Books, Oxford, UK.
McCabe, J. T. 2003. Sustainability and livelihood diversification among the Maasai of Northern Tanzania. Human Organisation 62(2):100-111. http://dx.doi.org/10.17730/humo.62.2.4rwrt1n3xptg29b8

McCabe, J. T., P. W. Leslie, and L. DeLuca. 2010. Adopting cultivation to remain pastoralists: the diversification of Maasai livelihoods in northern Tanzania. Human Ecology 38(3):321-334. http://dx.doi.org/10.1007/s10745-010-9312-8

McCabe, J. T., N. M. Smith, P. W. Leslie, and A. L. Telligman. 2014. Livelihood diversification through migration among a pastoral people: contrasting case studies of Maasai in Northern Tanzania. Human Organization 73(4):389-400. http://dx.doi. org/10.17730/humo.73.4.vkr10nhr65g18400

McGregor, J. A. 2007. Researching wellbeing: from concepts to methodology. Pages 316-350 in I. Gough and J. A. McGregor, editors. Wellbeing in developing countries: from theory to research. Cambridge University Press, Cambridge, UK.

McGregor, J. A., L. Camfield, A. Masae, and B. Promphaking. 2008. Wellbeing, development and social change in Thailand. Thammasat Economic Journal 26(2):1-27.

McGregor, J. A., and A. Sumner. 2010. Beyond business as usual: what might 3-D wellbeing contribute to MDG momentum? IDS Bulletin 41(1):104-112. http://dx.doi.org/10.1111/j.1759-5436.2010.00111. $\underline{\mathrm{X}}$

McShane, T. O., P. D. Hirsch, T. C. Trung, A. N. Songorwa, A. Kinzig, B. Monteferri, D. Mutekanga, H. Thang, J. L. Van, Dammert, M. Pulgar-Vidal, M. Welch-Devine, J. P. Brosius, P. Coppolillo, and S. O'Connor. 2011. Hard choices: making tradeoffs between biodiversity conservation and human well-being. Biological Conservation 144(3):966-972. http://dx.doi.org/10.1016/ j.biocon.2010.04.038

Miller, B. W., P. W. Leslie, and J. T. McCabe. 2014. Coping with natural hazards in a conservation context: resource-use decisions of Maasai households during recent and historical droughts. Human Ecology 42(5):753-768. http://dx.doi.org/10.1007/ s10745-014-9683-3

Msoffe, F. U., M. Y. Said, J. O. Ogutu, S. C. Kifugo, J. de Leeuw, P. Van Gardingen, and R. S. Reid. 2011. Spatial correlates of landuse changes in the Maasai-Steppe of Tanzania: implications for conservation and environmental planning. International Journal of Biodiversity and Conservation 3(7):280-290.

Mtui, D., N. Owen-Smith, and C. Lepczyk. 2017. Assessment of wildlife population trends in three protected areas in Tanzania from 1991 to 2012. African Journal of Ecology 55:305-315. http:// dx.doi.org/10.1111/aje.12354

Ndagala, D. K. 1982. 'Operation Imparnati' the sedentarization of the pastoral Maasai in Tanzania. Nomadic Peoples 10:28-39.

Ndagala, D. K. 1992. Territory, pastoralists and livestock: resource control among the Kisongo Maasai. Uppsala Studies in Cultural Anthropology, Uppsala University, Uppsala, Sweden. Amqvist och Wicksell, Stockholm.

Nelson, F., C. Foley, L. S. Foley, A. Leposo, E. Loure, D. Peterson, M. Peterson, T. Peterson, H. Sachedina, and A. Williams. 2010. Payments for ecosystem services as a framework for community- 
based conservation in northern Tanzania. Conservation Biology 24(1):78-85. http://dx.doi.org/10.1111/j.1523-1739.2009.01393.x

Nussbaum, M. C. 2011. Creating capabilities: the human development approach. Harvard University Press, Cambridge, Massachusetts, USA. http://dx.doi.org/10.4159/harvard.9780674061200

Olson, D. M., and E. Dinerstein. 1998. The Global 200: a representation approach to conserving the Earth's most biologically valuable ecoregions. Conservation Biology 12 (3):502-515. http://dx.doi.org/10.1046/j.1523-1739.1998.012003502. $\underline{\mathrm{x}}$

O’Malley, M. E. 2000. Cattle and cultivation: changing land use and labor patterns in pastoral Maasai livelihoods, Loliondo Division, Ngorongoro District, Tanzania. Dissertation. University of Colorado, Denver, Colorado, USA.

Organisation for Economic Co-operation and Development (OECD). 2017. Measuring well-being and progress: well-being research. OECD, Paris, France. [online] URL: http://www.oecd. org/statistics/measuring-well-being-and-progress.htm

Prins, H. H. T., and P. E. Loth. 1988. Rainfall patterns as background to plant phenology in northern Tanzania. Journal of Biogeography 15(3):451-463. http://dx.doi.org/10.2307/2845275

Sachedina, H. T. 2008. Wildlife is our oil: conservation, livelihoods and NGOs in the Tarangire Ecosystem, Tanzania. Dissertation. Oxford University Centre for the Environment, Oxford University, Oxford, UK.

Schlosberg, D. 2013. Theorising environmental justice: the expanding sphere of a discourse. Environmental Politics 22:37-55. http://dx.doi.org/10.1080/09644016.2013.755387

Schreckenberg, K., P. Franks, A. Martin, and B. Lang. 2016. Unpacking equity for protected area conservation. Parks 22 (2):11-26. http://dx.doi.org/10.2305/IUCN.CH.2016.PARKS-22-2KS. en

Sen, A. 1985. Commodities and capabilities. Oxford University Press, New Delhi, India.

Silverman, D. 2006. Interpreting qualitative data: methods for analyzing talk, text, and interaction. Sage, London, UK.

Smith, N. M. 2012. Maasai and the tanzanite trade: new facets of livelihood diversification in northern Tanzania. Dissertation. University of Colorado, Boulder, Colorado, USA.

Smith, N. M. 2014. Gender and livelihood diversification: Maasai women's market activities in Northern Tanzania. Journal of Development Studies 51:305-318. http://dx.doi.org/10.1080/0022$\underline{0388.2014 .957278}$

Spencer, P. 1993. Becoming Maasai, being in time. Pages 140-156 in T. Spear and R. Waller, editors. Being Maasai: ethnicity and identity in East Africa. James Currey, London, UK.

Springer, J., and J. Campese. 2011. Conservation and human rights: key issues and contexts. Scoping paper for the conservation initiative on human rights. Conservation Initiative on Human Rights, Arlington, Virginia, USA. [online] URL: https://static1. squarespace.com/static/57add7399f745649fc9e41a6/ t/57c81744cd0f68f5c7332cf4/1472730949495/Conservation and_Human_Rights_Key_Issues_and_Contexts.pdf
Stiglitz, J., A. Sen, and J. Fitoussi. 2009. Report by the commission on the measurement of economic performance and social progress. [online] URL: http://ec.europa.eu/eurostat/documents/118025/118123/ Fitoussi+Commission+report

Sullivan, S. 2002. How sustainable is the communalizing discourse of 'new' conservation? The masking of difference, inequality and aspiration in the fledging 'conservancies' of Namibia. Pages 158-187 in D. Chatty and M. Colchester, editors. Conservation and mobile indigenous people: displacement, forced settlement and sustainable development. Berghahn, Oxford, UK.

Wangui, E. E. 2008. Development interventions, changing livelihoods, and the making of female Maasai pastoralists. Agriculture and Human Values 25(3):365-378 http://dx.doi. org/10.1007/s10460-007-9111-z

Wood, G. 2007. Using security to indicate wellbeing. Pages 109-132 in I. Gough and J. A. McGregor, editors. Wellbeing in developing countries: from theory to research. Cambridge University Press, Cambridge, UK.

Woodhouse, E., K. M. Homewood, E. Beauchamp, T. Clements, J. T. McCabe, D. Wilkie, and E. J. Milner-Gulland. 2015. Guiding principles for evaluating the impacts of conservation interventions on human well-being. Philosophical Transactions of the Royal Society of London B 370(1681):20150103. http://dx.doi. org/10.1098/rstb.2015.0103

Wright, V. C. 2017. Turbulent terrains: the contradictions and politics of decentralized conservation. Conservation and Society 15(2):157-167. http://dx.doi.org/10.4103/cs.cs $15 \quad 33$

Zafra-Calvo, N., U. Pascual, D. Brockington, B. Coolsaet, J. A. Cortes-Vazquez, N. Gross-Camp, I. Palomo, and N. D. Burgess. 2017. Towards an indicator system to assess equitable management in protected areas. Biological Conservation 211:134-141 http://dx.doi.org/10.1016/j.biocon.2017.05.014 